JURNAL KETAHANAN NASIONAL

ISSN: 0853-9340 (Print), ISSN: 2527-9688 (Online)

Online sejak 28 Desember 2015 di: http:/jurnal.ugm.ac.id/JKN

VOLUME 23

No. 1, 27 April 2017

Halaman 104-122

\title{
Model Traffic Separation Scheme (TSS) Di Alur Laut Kepulauan Indonesia (AIKI) I Di Selat Sunda Dalam Mewujudkan Ketahanan Wilayah
}

\author{
Dyan Primana Sobaruddin \\ Pusat Hidrografi dan Oseanografi TNI Angkatan Laut (Pushidrosal) \\ Email: dyanmaxp@gmail.com \\ Armaidy Armawi \\ Fakultas Filsafat Universitas Gadjah Mada \\ Email: armaidy@ugm.ac.id \\ Edhi Martono \\ Fakultas Pertanian Universitas Gadjah Mada \\ Email: edhi.martono@ugm.ac.id
}

\begin{abstract}
Maritime traffic increase consequently would make the intensity of the ASL surveillance respectively. Indonesia owned several vital and important straits for maritime traffics, and one of them wass Sunda Straits, which was part of the ASL I connecting Indian Ocean and South China Sea and vice versa. The objectives of the research were (1) to created system model of Traffic Separation Scheme (TSS) in the ASL I Sunda Straits, (2) to studied the impact of TSS model to the territorial resilience of Sunda Straits.

This research showed that the best TSS model in Sunda Straits was the solution-2 where TSS laided on western side of Sangiang Island, which was maritime channel in between Panjurit Island and Sangiang Island with still regard the ASL I, and also considered the existing danger of navigation of Koliot Reef by installing an aids to the navigation. The Eigen Value Matrix generated from the TSS Solution-2 model would guarantee Sunda Straits from the security threat, danger of navigation and risk environmental damages, and it would make ease the law enforcement through the straits due to foreign ships had to sailed over this TSS.
\end{abstract}

\section{Keywords: Traffic Separation Scheme (TSS), Sunda Straits, Territorial Resilience}

\begin{abstract}
ABSTRAK
Peningkatan lalu lintas pelayaran menjadikan semakin berat tugas pengawasan jalur laut. Indonesia mempunyai beberapa selat yang sangat vital sebagai jalur pelayaran yaitu salah satunya adalah Selat Sunda dimana selat ini merupakan bagian dari Alur Laut Kepulauan Indonesia (ALKI) I, yang menghubungkan perairan Samudera Hindia melewati Selat Karimata menuju Laut China Selatan atau sebaliknya. Penelitian ini bertujuan untuk (1) Membuat model sistem Traffic Separation Scheme (TSS) di Alur Laut Kepulauan Indonesia (ALKI) I Selat Sunda, 2) Mengkaji dampak pembangunan model TSS bagi ketahanan wilayah Selat Sunda.

Penelitian ini menunjukkan bahwa Model TSS di Selat Sunda yang terbaik adalah solusi-2 dimana TSS berada di sebelah barat Pulau Sangiang, yaitu alur pelayaran di antara Pulau Panjurit dan Pulau Sangiang dengan tetap memperhatikan ALKI-I yang sudah ada, selain itu untuk keberadaan bahaya navigasi di Terumbu Koliot maka diletakkan SBNP. Model TSS Solusi-2 hasil perhitungan Matriks Eigen Value dilihat dari segi ketahanan wilayah
\end{abstract}


Selat Sunda membuat terjaminnya perairan Selat Sunda dari bahaya keamanan, bahaya navigasi pelayaran serta bahaya pencemaran lingkungan, mempermudah penegak hukum dalam melaksanakan pengawasan karena setiap kapal asing yang akan melewati Selat Sunda harus melewati TSS ini.

\section{Kata Kunci: Traffic Separation Scheme (TSS), Selat Sunda, Ketahanan Wilayah}

\section{PENGANTAR}

Negara-negara Asia Timur sangat tergantung pada kawasan perairan Asia Tenggara untuk kelangsungan pembangunan ekonomi mereka. Semakin banyak dan semakin meningkatnya lalu lintas di Alur Laut Kepulauan semakin berat tugas pengawasan jalur laut, bukan hanya dalam perlindungan lingkungan laut dan lalu lintas perdagangan tetapi juga ancaman pembajakan. Laporan IMO menyebutkan pada tahun 1994, dilaporkan terjadi pembajakan sebanyak 90,40\% di antaranya terjadi di perairan Asia, 22\% di perairan Asia Tenggara dan 14\% di Laut Cina Selatan. Angka-angka tersebut bisa melonjak tajam, seiring dengan dinamika ekonomi Asia Pasifik dan liberalisasi perdagangan.

Jalur transportasi minyak dan gas untuk kebutuhan energi di Asia Timur selain melalui Selat Malaka, adalah di Selat Sunda, Selat Lombok. Oleh sebab itu ketiganya merupakan selat vital bagi negara-negara Asia Timur, khususnya Cina dan Jepang. Bilamana terjadi hambatan pelayaran di Selat Malaka maka jalur alternatif paling dekat adalah Selat Sunda. Penggunaan Selat Sunda juga mengantisipasi jika titik kulminasi akibat perang terbuka antara Cina dan USA, dimana jalur Selat Malaka dipastikan "tersumbat". Maka Selat Sunda dianggap rute alternatif tersingkat dari jalur-jalur lazimnya. Di sisi lain, potensi ini merupakan keuntungan geopolitik Indonesia dari negaranegara yang terlibat konflik. Betapa sangat urgensi Selat Sunda dan alur-alur laut lain di mata dunia, karena banyak negara tergantung pada wilayah perairannya (Pranoto, 2012).
Selat Sunda merupakan bagian dari Alur Laut Kepulauan Indonesia (ALKI) I, yang menghubungkan perairan Samudera Hindia melewati Selat Karimata menuju Laut China Selatan atau sebaliknya. ALKI merupakan konsekuensi Indonesia sebagai negara kepulauan setelah pemerintah Indonesia meratifikasi Hukum Laut Internasional UNCLOS 1982 melalui Undang-Undang RI Nomor 17 Tahun 1985. Indonesia telah menetapkan tiga ALKI sebagai jalur lintas kapal asing dalam pelayaran dari suatu laut bebas (ZEE) ke laut bebas lainnya yang mencakup jalur udara di atasnya (Buntoro, 2012:95). Selat Sunda adalah rute yang biasa digunakan untuk pelayaran internasional. Pada perairan ini juga terdapat jalur penyeberangan dari Pulau Jawa (pelabuhan Merak) ke Pulau Sumatera (pelabuhan Bakauheni) yang dioperasikan oleh Angkutan Sungai Danau dan Penyeberangan (ASDP) Kementerian Perhubungan RI. Kepadatan lalu lintas Laut tersebut meningkatkan potensi terjadinya kecelakaan di laut akibat tubrukan. Hal ini perlu pemecahan permasalahan untuk meminimalisir terjadinya kecelakaan laut.

Penelitian ini bertujuan untuk membuat model sistem Traffic Separation Scheme (TSS) di Alur Laut Kepulauan Indonesia (ALKI) I Selat Sunda dan mengkaji dampak pembangunan model TSS bagi ketahanan wilayah Selat Sunda. Metode penelitian yang digunakan yaitu penelitian lapangan dilaksanakan untuk pengumpulan data relevan dengan pengambilan sampel langsung 
di lapangan dan penelitian laboratorium dikonsentrasikan pada proses/pekerjaan kartografis untuk perhitungan secara kartometris maupun penggambaran pada Peta Laut Indonesia yang secara resmi berlaku pada lokasi penelitian.

\section{PEMBAHASAN}

\section{Letak Geografis Selat Sunda.}

Selat Sunda adalah perairan yang menghubungkan Laut Jawa dan Samudera Hindia, yang memisahkan Pulau Sumatera dan Pulau Jawa. Secara geografis, menggunakan gambar di Selat Sunda di sebelah utara dibatasi oleh garis yang menghubungkan dari barat ke timur yaitu dari Tanjung Sumur Batu pada posisi koordinat $5^{\circ} 50^{\prime}$ lintang selatan (LS) dan $105^{\circ} 47^{\prime}$ bujur timur (BT), di pantai bagian selatan Pulau Sumatera ke Tanjung Pujut pada posisi koordinat $5^{\circ} 53^{\prime}$ lintang selatan (LS) $105^{\circ} 02^{\prime}$ bujur timur (BT) di pantai sebelah barat laut Pulau Jawa. Sedangkan di sebelah selatan dibatasi garis yang menghubungkan dari barat ke timur yaitu Tanjung Guha Kolak pada posisi koordinat $6^{\circ} 50^{\prime}$ lintang selatan (LS) dan $105^{\circ} 15^{\prime}$ bujur timur (BT) di pantai barat daya Pulau Jawa ke Tanjung Cuku Balimbing pada posisi koordinat $5^{\circ} 56$; lintang selatan (LS) dan $105^{\circ} 33^{\prime}$ bujur timur (BT) di pantai sebelah selatan Pulau Sumatera. (IHO, 2002; 16).

\section{Bahaya Navigasi di Selat Sunda.}

Sebagai salah satu selat yang sangat penting, Alur Laut Kepulauan Indonesia

Gambar 1

Selat Sunda

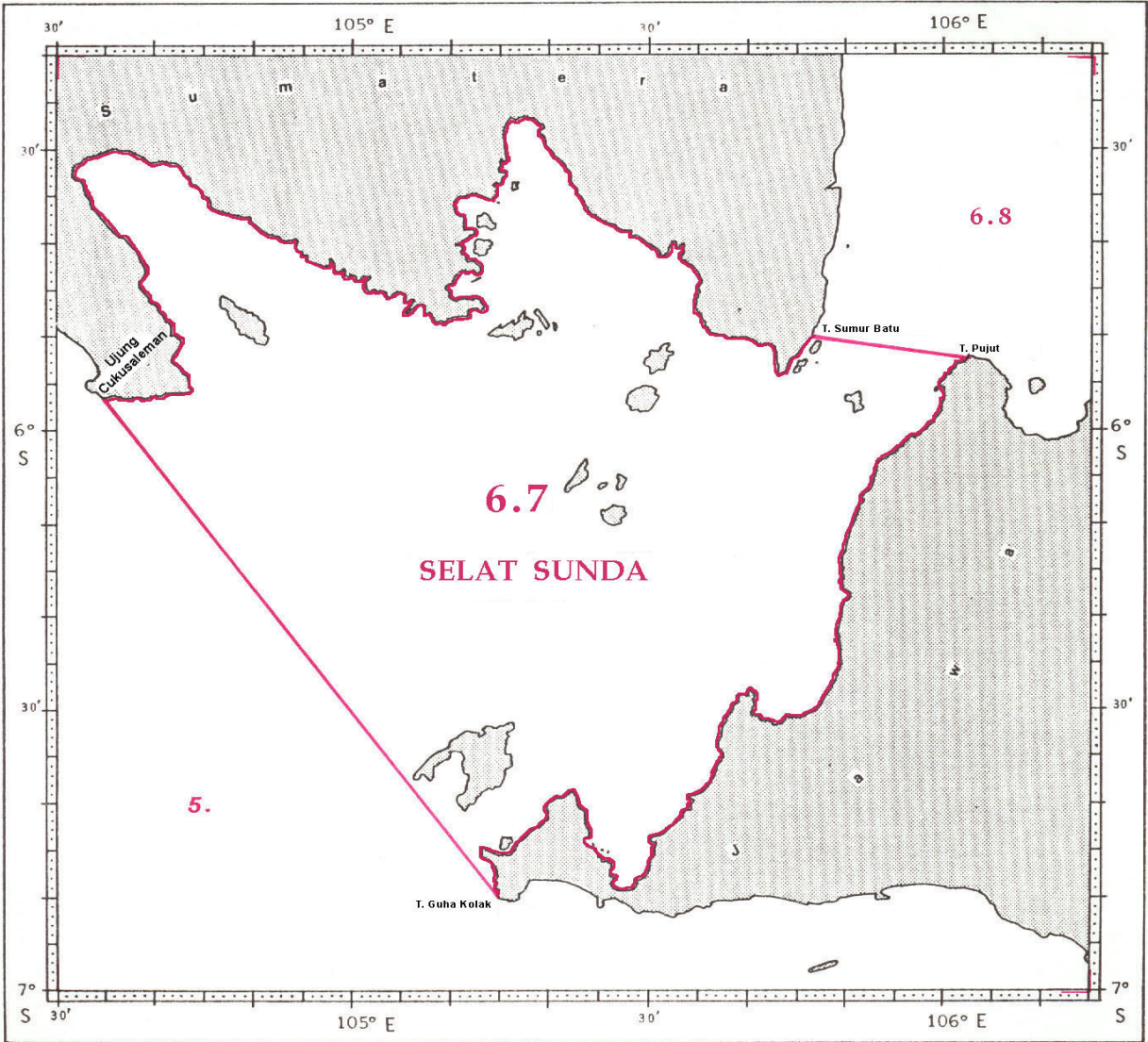

Sumber: IHO, 2002 
(ALKI) I mempunyai jalur pelayaran yang paling lebar di Selat Sunda dengan jarak 52 mil laut di perairan bagian selatan Selat Sunda dan sementara itu terdapat koridor jalur pelayaran paling sempit di Selat Sunda bagian utara dengan jarak 2,2 mil laut, akibat terdapat beberapa bahaya navigasi seperti karang, kedangkalan dan kerangka kapal. Salah satu gugusan karang yang terletak dekat alur ALKI I adalah Terumbu Koliot.

Terumbu Koliot berada kurang lebih 1 mil laut di sebelah timur laut poros ALKI I. Terumbu Koliot adalah sebuah terumbu karang yang terdapat di sebelah barat laut dari Pulau Sangiang yang terdapat di perairan Selat Sunda. Terumbu Koliot sangat berbahaya bagi kapal-kapal yang melintas di ALKI I yang akan menuju Samudera Hindia dari Laut Jawa maupun yang akan menuju Laut Jawa atau sebaliknya. Pada Terumbu Koliot tidak terdapat Sarana Bantu Navigasi Pelayaran (SBNP) yang dipasang untuk memberikan tanda bahaya bagi kapal-kapal yang melintas. Selain Terumbu Koliot terdapat Terumbu Gosal yang selalu dapat dikenali dari perubahan warna dan hempasan arus. Bahaya ini terletak di Merkah sebelah barat laut Pulau Tempurung. Pada jarak $50 \mathrm{~m}$ dari batu tersebut sudah terdapat kedalaman $9 \mathrm{~m}$ sampai $23 \mathrm{~m}$.

\section{Kedalaman Perairan Dan Peta Laut Indonesia Di Selat Sunda}

Kedalaman yang aman untuk dilayari oleh kapal-kapal yang melintas di sekitar Selat Sunda berkisar antara 10 meter sampai dengan 1.885 meter, dengan dasar laut karang, lumpur pasir, dan pasir. Infromasi data hidrografi di perairan Selat Sunda dapat dilihat pada Peta Laut Indonesia nomor 71 pengeluaran kedelapan, September 2010 (Dishidros,2010) dan Peta Laut Indonesia nomor 71A pengeluaran ketiga 2008 (Dishidros, 2008).

\section{Cagar Alam, Taman Nasional, Daerah Berbahaya Dan Daerah Latihan TNI AL}

Berdasarkan Peta Laut Indonesia nomer 71 edisi ke-12 bulan September 2008, di Selat Sunda juga terdapat daerah cagar alam flora dan fauna, daerah cagar alam laut, taman nasional dan daerah wisata antara lain di Pulau Sangiang, Pulau Panaitan dan Ujung Kulon (Pulau Jawa). Perairan di sekitar Pulau Rakata, Pulau Rakata Kecil, Pulau Anakrakata dan Pulau Sertung dinyatakan sebagai daerah berbahaya karena sewaktu-waktu Gunung Krakatau di Pulau Rakata bisa erupsi. Di samping itu juga terdapat Daerah Latihan TNI AL yang berada di Teluk Lampung, merupakan bagian barat Selat Sunda, di daerah latihan itu Tentara Nasional Indonesia Angkatan Laut melakukan latihan peperangan laut.

\section{Lalu Lintas Pelayaran Kapal Dari Dan Ke Samudera Hindia}

Selat Sunda merupakan salah satu jalur pelayaran yang merupakan bagian dari ALKI I yang dilalui oleh lalu lintas kapal kargo, kapal tanker, kapal tunda, kapal ikan dan kapal militer serta kapalkapal yang menggunakan Selat Sunda untuk melintas dari Samudera Hindia ke Laut Jawa atau melanjutkan ke Samudera Pasifik atau sebaliknya. Jumlah kapal-kapal yang berlayara melintasi Selat Sunda meningkat dari waktu ke waktu. 
Tabel 1

Jumlah Kapal Melintasi Selat Sunda Tahun 2007 - 2015

\begin{tabular}{|c|c|c|c|c|c|c|c|c|c|c|c|}
\hline \multirow{2}{*}{ NO } & \multirow{2}{*}{ JENIS KAPAL } & \multicolumn{9}{|c|}{ TAHUN } & \multirow[b]{2}{*}{ JUMLAH } \\
\hline & & 2007 & 2008 & 2009 & 2010 & 2011 & 2012 & 2013 & 2014 & 2015 & \\
\hline 1 & KRI (Kapal Perang RI) & 48 & 19 & 38 & 16 & 30 & 16 & 38 & 42 & 168 & 415 \\
\hline 2 & $\begin{array}{l}\text { KAL (Kapal Angkatan } \\
\text { Laut) }\end{array}$ & & & 2 & & 5 & & & & 0 & 7 \\
\hline 3 & Kapal Perang Asing & 2 & 4 & 3 & 9 & 6 & 7 & 1 & 3 & 6 & 41 \\
\hline 4 & Kapal Kargo & 962 & 741 & 744 & 689 & 668 & 3957 & 3803 & 2663 & 2339 & 16566 \\
\hline 5 & Kapal Tanker & 505 & 442 & 618 & 509 & 403 & 2550 & 2873 & 1780 & 1465 & 11145 \\
\hline 6 & Kapal Kontainer & 128 & 99 & 118 & 64 & 62 & & & & 65 & 536 \\
\hline 7 & Kapal Pesiar & - & & 7 & 4 & 5 & 3 & & & 0 & 19 \\
\hline 8 & Kapal Feri & 4 & 2 & 3 & 35 & 30 & 85 & 57 & 32 & 25 & 273 \\
\hline 9 & Kapal Tunda (Tug Boat) & 27 & 53 & 53 & 1 & 1 & & & & 0 & 135 \\
\hline 10 & Kapal Tongkang & - & 1 & & 15 & 14 & & & & 0 & 30 \\
\hline 11 & Kapal Survei & - & & 8 & 8 & 19 & & & & 0 & 35 \\
\hline 12 & Kapal Ikan Indonesia & 6 & 12 & 19 & 8 & 10 & & 3 & 1 & 0 & 59 \\
\hline 13 & LCT & & & 33 & 1 & & 3 & 2 & & 0 & 39 \\
\hline 14 & KPLP & & & 3 & 1 & & & 1 & & 0 & 5 \\
\hline 15 & $\begin{array}{l}\text { Tdk Teridentifikasi } \\
\text { jenisnya }\end{array}$ & 4 & 1 & 3 & 2 & & & 16 & 20 & 37 & 46 \\
\hline & JUMLAH & 1686 & 1374 & 1652 & 1362 & 1253 & 6621 & 6794 & 4541 & & 29351 \\
\hline
\end{tabular}

Sumber : Puskodal Lanal Banten,

Berdasarkan pantauan dari Pusat Komando dan Pengendali (Puskodal) Pangkalan Angkatan Laut (Lanal) Banten, jumlah kapal yang melintas dari tahun 2007 hingga tahun 2015 adalah 29.351 kapal, yang terdiri dari berbagai jenis, di antaranya adalah kapal kargo, kapal kontainer, kapal tanker, kapal perang, kapal pesiar, kapal ikan dan lain sebagainya. (lihat tabel 1)

\section{Lalu Lintas Pelayaran Kapal Feri Penyeberangan Bakauheni-Merak}

Sebelah barat Selat Sunda, di daratan Pulau Sumatera, terdapat pelabuhan penyeberangan yang menghubungkan Pulau Sumatera yaitu di pelabuhan Bakauheni dan Pulau Jawa yaitu di pelabuhan Merak, jarak antara keduanya $\pm 30 \mathrm{Km}$ dengan waktu tempuh kapal penyeberangan sekitar 1,5 jam.
Bakaheuni merupakan daerah pelabuhan penyeberangan kapal feri di ujung selatan Pulau Sumatera yang lalu lintas penyeberangannya cukup padat sehingga mampu menyerap cukup banyak tenaga kerja melalui sektor perdagangan, perikanan dan industri kecil seperti industri makanan dan bahan bangunan. Pelabuhan penyeberangan Bakauheni di bawah penanganan dan pengelolaan PT. ASDP (Persero) mempunyai 4 dermaga Kapal RoRo, 1 dermaga Kapal Ro-Ro jenis plengsengan dan 1 dermaga Kapal Cepat jenis ponton.

Di sebelah timur Selat Sunda terdapat pelabuhan penyeberangan yang berada di Pulau Merak, Kota Cilegon, Banten yang menghubungkan Pulau Jawa dengan Pulau Sumatera. Setiap hari terdapat beberapa kapal feri yang melakukan penyeberangan bagi kendaraan, manusia dan barang dari pelabuhan 
Merak ke pelabuhan Bakauheuni, Lampung, begitupun sebaliknya. Diperoleh keterangan bahwa jumlah kapal feri yang beroperasi setiap hari adalah 29 kapal dan terjadi 90 trayek setiap harinya.

\section{Tubrukan Kapal Di Selat Sunda}

Akibat mulai padatnya kapal-kapal yang melintas di Selat Sunda baik kapal yang berlayar di ALKI I maupun kapal-kapal feri yang memotong jalur ALKI I, di Selat Sunda sering terjadi kecelakan tubrukan kapal di laut. Dari data yang diperoleh, pada tahun 2014 telah terjadi kecelakaan kapal di Selat Sunda, yaitu tubrukan antara KMP Jatra III dan MT. Soechi Chemical VII pada tanggal 28 Januari 2014, Pukul 07.30 WIB, antara KMP Portlink dan Cargo FGA - 138 pada tanggal 01 Oktober 2014, Pukul 11.13 WIB, tubrukan antara KMP Bahuga Jaya dan MT. Norgas Chatinka pada tanggal 26 September 2012 Pukul 04.50 WIB dan antara KMP Marinsa dan MV. Qihang pada tanggal 03 Mei 2014 pukul 02.10 WIB (Lanal Banten, 2016). Di kawasan perairan Selat Sunda memang daerah lalu lintas jalur pelayaran umum dan bebas serta minimnya rambu pelayaran.

\section{Geopolitik Selat Sunda}

Geopolitik menjadi pendekatan bagi setiap negara dalam menentukan kebijakan yang berdasarkan pada situasi geografis negara. Setiap negara menggunakan pendekatan geostrategik melalui kebijakan sebagai alat dan sarana mencapai geopolitiknya. Tidak hanya dalam cara pandang darat, geopolitik juga mengkaji daerah perairan seperti selat dan jalur perdagangan laut di dunia. Enam dari sembilan choke point di dunia yang sangat vital sebagai jalur transportasi laut untuk perdagangan dan jalur minyak berada di Indonesia yaitu Selat
Malaka, Selat Singapura, Selat Sunda, Selat Lombok, Selat Makasar, Selat Ombai dan Selat Wetar (Buntoro, 2016:11). Keenam selat strategis itu yang terdapat di perairan Indonesia tersebut merupakan jalur lalu lintas pelayaran paling ramai dan tepat berada pada jalur ALKI.

Jumlah kapal yang melintasi Selat Malaka menunjukkan peningkatan dari tahun sampai 2000 sampai dengan tahun 2009 dan diprediksikan bahwa pada tahun 2020 akan meningkat sampai dua kali lipat dari tahun 2009 (Shahryari, dkk, 2009 : 16).

Dengan semakin padatnya lalu lintas pelayaran di Selat Malaka dan Singapura dari tahun ke tahun, maka banyak kapal yang melintas dari Samudera Hindia ke Laut Cina Selatan yang awalnya melalui Selat Malaka dan Singapura akan berubah melalui ALKI I, khususnya perairan Selat Sunda. Menurut Paonganan (2012) Direktur Eksekutif Indonesia Maritim Institut (IMI), Selat Sunda merupakan bagian dari ALKI I yang berada pada perlintasan kapal-kapal dagang dan kapal militer, kapal-kapal ini melintas bebas dan negara berkewajiban mengamankan selama berada dalam wilayah teritorial NKRI. Melihat kondisi hidro-oseanografi di Selat Malaka yang lambat laun semakin mendangkal akibat dari sedimentasi serta semakin padatnya jalur pelayaran maka sebagian besar kapal berukuran besar akan melintas di Selat Sunda, karena memiliki perairan yang cukup dalam.

Geopolitik Selat Sunda sebagai salah satu potensi di Indonesia dalam aspek politik, ekonomi, sosial budaya serta pertahanan dan keamanan bisa menjadi sumber kerentanan dan kelemahan. Selat Sunda sebagai salah satu choke point dunia yang strategis menunjukkan bahwa jalur kehidupan ekonomi, politik dan pertahanan serta keamanan kawasan Asia- 
Pasifik tergantung kepada stabilitas, kebijakan luar negeri dan geopolitik Indonesia. Dengan ditetapkannya TSS di ALKI I di Selat Sunda, Indonesia dapat melakukan kontrol terhadap choke point di dunia.

\section{Teknik Kartometris Penentuan TSS ALKI I Segmen Selat Sunda}

Kartometri merupakan salah satu metoda kajian teoritis di atas meja (table top study) dengan melakukan pengukuranpengukuran secara kartografis antara objekobjek tergambar, sehingga didapatkan besaran baringan (arah kompas) dan jarak ataupun didapatkan ekstraksi posisi. Pada peta laut, terdapat satuan ukuran yang bersesuaian diterapkan untuk berbagai peruntukan, yaitu mil laut, satuan ukuran panjang yang lazim diterapkan pada navigasi pelayaran, satuan ukuran yang setara dengan 1852 meter. Mil laut dapat dikonversi dengan mudah ke dalam menit (') dalam satuan seper-enampuluh derajad $\left(^{\circ}\right)$ lintang maupun bujur. Mil laut juga mudah dikonversi ke dalam satuan kecepatan knot yang merupakan satuan kecepatan mil laut per jam.

Penentuan TSS yang digambarkan pada peta menggunakan sistem kartometrik dimana daerah yang akan dibuat TSS Selat Sunda pada bagian yang paling sempit yaitu antara Pulau Sangiang dan Pulau Panjurit. Penentuan TSS di Selat Sunda secara kartometrik merupakan suatu cara penelusuran / penarikan garis batas Traffic Separation Scheme pada peta kerja dengan melakukan pengukuran / penghitungan posisi titik, jarak serta luas cakupan wilayah dengan menggunakan peta laut Indonesia di wilayah Selat Sunda dengan sekala terbesar yaitu peta laut Indonesia nomer nomer 71A edisi ke-2 bulan Maret 2008 serta peta laut Indonesia nomor 71 sekala 1 : 500000 edisi ke-12 bulan September 2008, dengan mempertimbangkan posisi kedangkalan Terumbu Koliot.

Dalam menetapkan TSS tidak hanya sekedar menetapkan alurnya saja. Namun demikian sesuai dengan Peraturan Menteri Perhubungan nomor 68 tahun 2011 tentang Alur Pelayaran di Laut, maka merupakan alur pelayaran umum dan perlintasan. Penyelenggaraan alur pelayaran di laut itu dimaksudkan untuk ketertiban lalu lintas kapal, memonitor pergerakan kapal, mengarahkan pergerakan kapal, dan pelaksanaan hak lintas damai kapal-kapal asing. Penataan alur pelayaran di laut dilakukan untuk ketertiban lalu lintas kapal, keselamatan dan keamanan bernavigasi serta perlindungan lingkungan maritim. Komponen dari TSS itu sendiri terdiri dari TSS boundary, TSS lane, TSS lines, dan TSS zone. Di sebelah kiri kanan Selat Sunda banyak terdapat pelabuhan, Inshore Traffic Zones-nya juga harus diatur sangat ketat dengan perhubungan laut, bagaimana mengatur tataruang di situ. Di luar TSS harus ada Inshore Traffic Zones, sehingga baik kapal-kapal yang berlabuh jangkar maupun kapal-kapal yang tidak berkepentingan untuk melakukan manufer memiliki tempat juga.

Dalam penggambaran TSS di peta laut (Nautical Charts) harus diperhatikan batas-batasnya dan digambarkan dengan simbol-simbol sesuai dengan aturan dalam pembuatan peta laut yang telah ditetapkan oleh International Hydrography Organisation (IHO) di dalam publikasi standar dalam pembuatan peta laut yaitu publikasi S-4 IHO, Regulations Of The IHO For International (INT) Charts And Chart Specifications Of The IHO dan INT-1 atau Peta Nomor 1 yang berisi simbol dan singkatan untuk peta laut. Batasbatas pada TSS itu sangat penting sehingga 
kapal-kapal yang berlayar dapat memahami jalur perairan mana yang harus dilalui agar tetap terjamin keselamatan bernavigasi.

Penentuan TSS yang akan digambarkan pada peta laut menggunakan sistem kartometrik dimana daerah yang akan dibuat TSS Selat Sunda pada bagian yang paling sempit yaitu antara Pulau Sangiang dan Pulau Panjurit. Penentuan TSS di Selat Sunda secara kartometrik merupakan suatu cara penelusuran / penarikan garis batas Traffic Separation Scheme pada peta kerja dengan melakukan pengukuran / penghitungan posisi titik, jarak serta luas cakupan wilayah dengan menggunakan peta laut di wilayah Selat Sunda. Untuk mempermudah batasan perlintasan kapal maka garis tengah TSS merupakan garis tengah dari ALKI. Pada metode pertama ini batas tepi yang diambil jarak dari pulau terdekat adalah 10\% atau 225 meter dari Pulau Panjurit dan kedangkalan yang ada di Terumbu Koliot, hal ini sesuai ketentuan UNCLOS.

Berikut beberapa pemikiran yang dapat dikemukakan terkait penerapan TSS di Selat Sunda : (1) Lokasi TSS dua arah berada pada sumbu ALKI-I yang ada, yakni terletak antara Pulau Sumatera dan Pulau Sangiang. (2) Cakupan TSS sebaiknya tidak hanya di bagian utara, tetapi sudah dimulai sejak memasuki laut teritorial Indonesia di bagian selatan Selat Sunda hingga di Laut Jawa yang cukup ramai dengan kegiatan eksploitasi migas. (3) Pengaturan alur lalu lintas kapal mengikuti aturan berlawan arah jarum jam (counterclockwise), seperti yang berlaku di Selat Malaka dan Selat Singapura. (4) Pengaturan penyeberangan domestik agar lebih memprioritaskan dengan memperhatikan keberadaan kapal yang melintas di jalur TSS yang sekaligus sebagai ALKI. (5) Terkait pelaku penyeberangan domestik, tol laut, dan pelayaran lainnya perlu dikeluarkan peraturan Menteri Perhubungan atau minimal Peraturan Dirjen Perhubungan Laut agar tidak terjadi kecelakaan yang tidak diinginkan. (6) Penentuan TSS secara teknis diperlukan survei hidrografi detail, khususnya pada area yang relatif padat termasuk penyeberangan domestik MerakBakauheni dengan mendata seluruh bahaya navigasi yang ditemukan. (7) Membangun rambu suar yang diperlukan terutama di Karang Koliot dan tempat lain yang dipandang perlu untuk lebih menjamin TSS yang ditetapkan akan lebih terbantu dengan adanya tambahan SBNP tambahan ini. (8) Menyiapkan peta laut dan Electronic Navigational Chart (ENC) yang menggambarkan TSS ini secara jelas dengan skala yang lebih besar dari yang sudah ada sehingga memudahkan pengguna TSS dan penyeberangan domestik. (9) Manakala TSS sudah ditetapkan secara nasional, selanjutnya melaporkan pemberlakuannya kepada International Maritime Organization (IMO) agar memiliki legal aspect secara internasional (FGD, 11 Mei 2016).

Dari pendapat narasumber pada FGD di bidang kartografi, maka disiapkan 3 (tiga) model TSS di Selat Sunda pada peta laut Indonesia nomer 71A edisi ke-2 bulan Maret 2008 serta peta laut Indonesia nomor 71 sekala $1: 500$ 000 edisi ke-12 bulan September 2008, yaitu (1) Solusi pertama, yaitu sesuai dengan jalur ALKI I di Selat Sunda tanpa adanya TSS, sehingga kapal yang berlayar akan berpedoman terhadap poros ALKI I yang telah digambarkan di peta laut Indonesia tersebut. (2) Solusi kedua, yaitu dengan menggambarkan TSS di sebelah barat Pulau Sangiang, sehingga kapalkapal yang melintas baik yang dari Laut Jawa ke Samudera Hindia akan melintas jalur TSS yang telah ditetapkan. Untuk kapal-kapal feri penyeberangan dibuatkan daerah kewaspadaan (precaution areas) sehingga baik kapal-kapal 
feri penyeberangan yang memotong alur pelayaran utama TSS akan waspada saat berada di persimpangan, begitu juga dengan kapal-kapal yang melalui TSS. (3) Solusi ketiga, yaitu dengan menggambarkan TSS dengan menetapkan alur pelayaran bagi kapal yang berlayar dari Laut Jawa ke Samudera Hindia melewati sebelah barat Pulau Sangiang. Sedangkan bagi kapal-kapal yang berlayar dari Samudera Hindia ke Laut Jawa akan melintasi alur pelayaran sebelah timur Pulau Sangiang.

Pada solusi kedua dibuat precautionary area di dua tempat agar kapal-kapal yang melintas menjadi waspada dan dapat digunakan sebagai daerah penyeberangan kapal-kapal feri dari pelabuhan Merak ke Bakauheuni dan sebaliknya. Precautionary Area yang melintang dari Merak - Bakauheni mempunyai lebar 3.405 meter dan panjang 3.133 meter. Lebar TSS sebelah utara 4.865 meter dan sebelah selatan lebar 10.741 meter, sedangkan panjang TSS 28.521 meter.

Sebenarnya dengan ditetapkannya precaution area pada TSS tersebut di persilangan antara alur pelayaran utama bagi kapal yang melintas ALKI I dengan alur pelayaran kapal-kapal feri penyeberangan, akan membantu kewaspadaan bagi kapalkapal yang melintas ALKI I maupun yang akan berlayar memotong ALKI I.

Dari sisi jaminan keamanan dengan ditetapkan TSS di Selat Sunda, kapal-kapal akan mudah terpantau dan terkendalikan. Bagi kapal-kapal yang keluar dari jalur TSS yang telah ditetapkan dapat ditegor atau diperingatkan untuk tetap masuk di koridor alur pelayaran TSS yang sudah ditentukan, sehingga bagi TNI Angkatan Laut serta aparat penegak hukum di laut akan lebih mudah melakukan patroli menjaga keamanan di sekitar peraiaran Selat Sunda.
Jika dilihat dari sisi ekonomi, dengan ditetapkannnya TSS akan memberikan nilai ekonomi tambah bagi pembangunan daerah di sekitar Selat Sunda. Penetapan TSS seyogyanya diikuti oleh pembangunan fasilitas pendukung keselamatan navigasi pelayaran. Pada prinsipnya, semua kapal bebas bernavigasi tanpa harus dipungut bayaran. Akan tetapi, pemerintah dapat melakukan pungutan bagi kapal yang berlayar dengan memberikan fasilitas-fasilitas memberikan tambahan informasi bagi kapalkapal yang berlayar sehingga semakin terjamin keselamat bernavigasi.

Berdasarkan dari beberapa hasil wawancara dan FGD tentang penetapan TSS di Selat Sunda, diketahui bahwa penetapan TSS di Selat Sunda sangat diperlukan untuk menjamin keselamatan pelayaran di perairan tersebut seiring dengan peningkatan volume kapal-kapal yang berlayar melintas di ALKI I Selat Sunda. Selain terjaminnya keselamatan pelayaran, manfaat lain dari ditetapkannya TSS di Selat Sunda adalah terjaminnya keamanan perairan karena mudah terkontrol, peningkatan pembangunan daerah pesisir di sekitar Selat Sunda yang tentu saja akan meningkatkan pertumbuhan ekonomi masyarakat di sekitarnya, dan Taman Nasional di sekitar alur pelayaran terjamin kelestariannya.

\section{AHP Sebagai Penilaian Pendapat Pakar Penerapan TSS Atas Ketahanan Wilayah Pada ALKI I Selat Sunda}

Pendapat pakar menjadi salah satu acuan pada penelitian penerapan TSS atas ketahanan wilayah pada ALKI I Segmen Selat Sunda. Pelibatan pakar meliputi pejabat yang berkompeten dalam hal kemampuan teknis kebidangan dan penerapannya, yaitu pejabat Kementerian Polhukam sebagai pengawal kepentingan NKRI, Pejabat Kementerian 
Dyan Primana Sobaruddin, Armaidy Armawi, Edhi Martono -- Model Traffic Separation Scheme (TSS) Di Alur Laut Kepulauan Indonesia (AlKI) I Di Selat Sunda Dalam Mewujudkan Ketahanan Wilayah

Tabel 2

Matriks Hasil Hitung Gabungan Pendapat Pakar (Expert) Perbandingan Tingkat Kepentingan Elemen-Elemen Faktor Berdasarkan Focus Model Traffic Separation Scheme (TSS) Pada Alur Laut Kepulauan Indonesia (ALKI) I Di Selat Sunda Dalam Mewujudkan Ketahanan Wilayah

\begin{tabular}{|c|c|c|c|c|c|c|c|c|c|}
\hline FAKTOR & $\begin{array}{c}\text { Ting } \\
\text { NKRI }\end{array}$ & $\begin{array}{c}\text { Jak Pem } \\
\text { RI }\end{array}$ & Jak PBB & $\begin{array}{c}\text { Ting } \\
\text { IMO/ } \\
\text { IHO }\end{array}$ & $\begin{array}{c}\text { RapTek } \\
\text { Kom }\end{array}$ & VE & VP & VA & VB \\
\hline Ting NKRI & 1.00 & 4.66 & 6.43 & 6.43 & 6.88 & 4.21 & 0.535 & 3.16 & 5.90 \\
\hline Jak Pem RI & 0.21 & 1.00 & 3.50 & 4.36 & 5.16 & 1.76 & 0.224 & 1.36 & 6.09 \\
\hline Jak PBB & 0.21 & 0.23 & 1.00 & 1.48 & 3.55 & 0.76 & 0.097 & 0.62 & 6.38 \\
\hline Ting IMO/IHO & 0.16 & 0.23 & 0.68 & 1.00 & 3.00 & 0.59 & 0.075 & 0.48 & 6.41 \\
\hline \multirow[t]{5}{*}{ RapTek Kom } & 0.21 & 0.54 & 1.00 & 0.42 & 1.00 & 0.54 & 0.069 & 0.43 & 6.24 \\
\hline & & & & & & 7.87 & 1.00 & & 31.02 \\
\hline & & & & & & & & $\delta \max$ & 6.20 \\
\hline & & & & & & & & $\mathrm{CI}$ & 0.30 \\
\hline & & & & & & & & $\mathrm{CR}$ & 0.27 \\
\hline
\end{tabular}

Sumber: Olahan Peneliti

Keterangan :

VE

: Vektor Elemen

: Nilai rata-rata dari tiap-tiap faktor dalam matriks pendapat gabungan

VP

: Vektor Prioritas (Priority Vector)

: Nilai yang diacu untuk menentukan ranking

VA

: Vektor Antara hasil kali Faktor dengan VP

: Bilangan pengumpan (feeder) untuk menghitung VB

VB : Nilai Eigen VA/VP

: Bilangan pengumpan (feeder) untuk menghitung d max, CI dan CR

d max $\quad$ : Rerata dari VB

Perhubungan Laut sebagai pengawal kepentingan kebijakan Pemerintah RI, Pejabat Hukum sebagai pengawal kepentingan lembaga dunia PBB/UNO, Pejabat Pelayaran yang membawahi Selat Sunda sebagai pengawal kepentingan masyarakat maritim dunia yang tergabung dalam IMO/IHO. Pendapat pakar terangkum dalam suatu kuesioner baku sebagaimana tertera pada metodologi.

Lima faktor atas kepentingan aktor-aktor terhadap model Traffic Separation Scheme
CI

CR

Ting NKRI

JakPemRI

Jak PBB

Ting IMO/IHO

RapTek Kom
: Consistenci Index |Indeks Konsistensi adalah (d max-n)/(n-1)

: Concentration Ratio (Ratio Konsentrasi) CI/RI (RI adalah tetapan)

: Syarat konsistensi ditandai dengan nilai $\mathrm{CR}<10 \%$

: Kepentingan Nasional NKRI

: Kebijakan Pemerintah RI

: Kebijakan Lembaga Dunia (PBB) untuk penerapan UNCLOS'82

: Kepentingan Masyarakat Maritim Dunia

: Kepentingan Penerapan Teknologi Komunikasi Maritim

(TSS) pada Alur Laut Kepulauan Indonesia (ALKI) I di Selat Sunda dalam mewujudkan ketahanan wilayah, dengan elemen-elemen: (1) Faktor Kepentingan Nasional Negara Kesatuan Republik Indonesia (NKRI) . (2) Faktor Kepentingan Penerapan Kebijakan Pemerintah Republik Indonesia. (3) Faktor Kepentingan Penerapan Kebijakan Lembaga Dunia Perserikatan Bangsa-Bangsa (PBB). (4) Faktor Kepentingan Masyarakat Maritim Dunia yang terwadahi dalam International 
Maritime Organization (IMO) dan International Hydrography Organization (IHO). (5) Faktor Kepentingan Penerapan Teknologi Komunikasi Maritim, merupakan kepentingan aktor praktisi teknologi komunikasi dan kepentingan masyarakat maritim dunia. (Lihat tabel 2)

Hasil tertera pada tabel 2 tersebut di atas, dapat dilihat bahwa nilai Vektor prioritas sebagai indikator penentuan tingkat kepentingan aktor, berturut-turut adalah Faktor Kepentingan NKRI 0.535, Faktor Pemerintah Republik Indonesia 0.224, Faktor Kepentingan Penerapan Kebijakan Lembaga Dunia (PBB) 0.097, Faktor Kepentingan Masyarakat Maritim 0.075, Faktor Kepentingan Penerapan Teknologi Komunikasi Maritim 0.069. Indikator tersebut jelas menyebutkan bahwa dalam mewujudkan ketahanan wilayah, berdasarkan fokus model TSS pada Alur Laut Kepulauan Indonesia (ALKI) I di Selat Sunda, faktor kepentingan NKRI adalah yang utama, selanjutnya adalah faktor kepentingan penerapan kebijakan pemerintah Republik Indonesia. Dalam hal ini dapat difahami bahwa NKRI sebagai suatu negara, nilai pentingnya lebih dari kepentingan pemerintah RI mengingat bahwa pemerintahan yang sah merupakan salah satu komponen dari suatu negara yang berdaulat. Terkait dengan faktor kepentingan lain, bagi ketahanan wilayah pada Alur Laut Kepulauan Indonesia (ALKI) I di Selat Sunda, tetap merupakan hal penting. Selat Sunda yang telah ditetapkan menjadi salah satu dari jalur ALKI harus dapat menyangga dan menjembatani kepentingan nasional NKRI dengan kepentingan masyarakat dunia baik dalam bingkai PBB, IMO maupun IHO. Harmonisasi ini jika terganggu, pada akhirnya akan mengganggu ketahanan nasional pada wilayah tersebut.

Pada tampilan grafis hasil perhitungan matriks gabungan pendapat pakar atas elemenelemen faktor, tertera pada gambar 2. sebagai berikut :

Gambar 2

Hasil Hitung Gabungan Pendapat Pakar (Expert) Peringkat Elemen-Elemen Faktor Berdasar Kepentingan Aktor Terhadap Focus Model Traffic Separation Scheme (TSS) Pada Alur Laut Kepulauan Indonesia (ALKI) I Di Selat Sunda Dalam Mewujudkan Ketahanan Wilayah

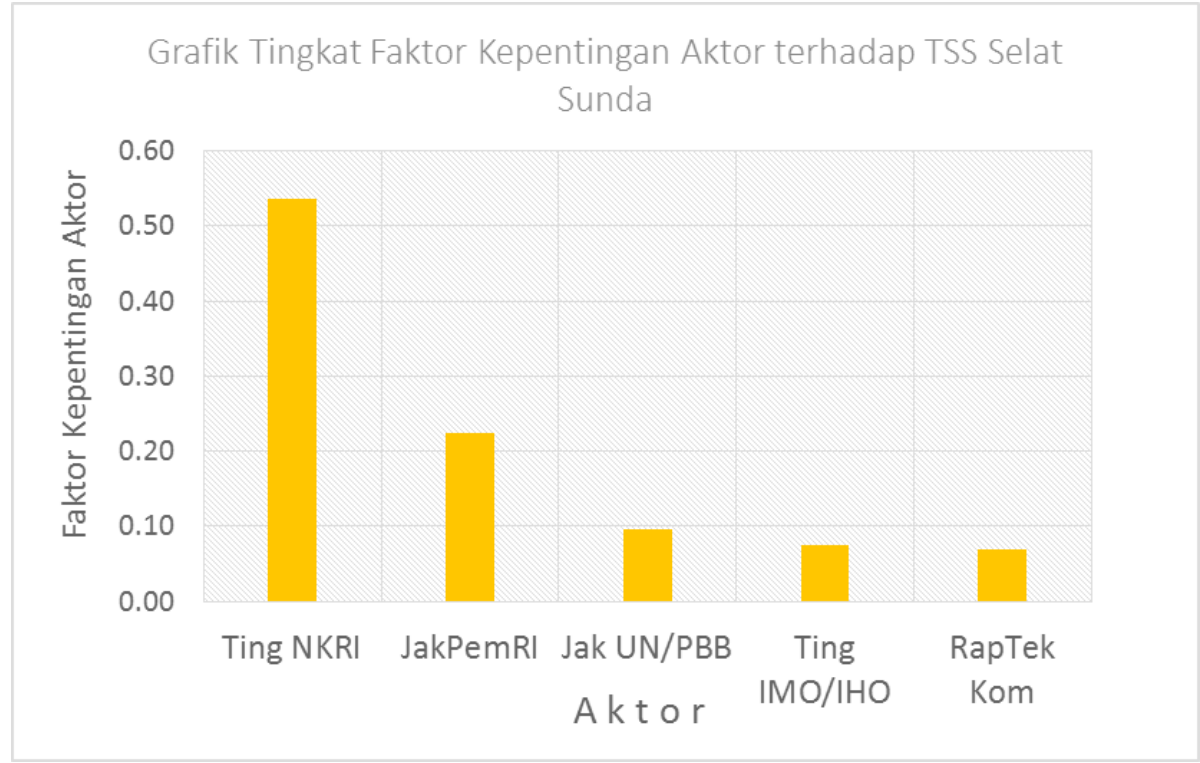

Sumber: Olahan Peneliti 
Dyan Primana Sobaruddin, Armaidy Armawi, Edhi Martono -- Model Traffic Separation Scheme (TSS) Di Alur Laut Kepulauan Indonesia (AlKI) I Di Selat Sunda Dalam Mewujudkan Ketahanan Wilayah

Tabel 3

Matriks Hasil Hitung Gabungan Eigen Value Pendapat Pakar (Expert) Tentang Kepentingan Aktor Terhadap Model Traffic Separation Scheme (TSS) Pada Alur Laut Kepulauan Indonesia (ALKI) I Di Selat Sunda Dalam Menciptakan Kelancaran SLOC/SLOT

\begin{tabular}{lrrrrrrr}
\hline AKTOR & VP_F2 & VP_F3 & VP_F4 & VP_F5 & VP_F6 & VP_FCUS & VP_FGAB \\
\hline NKRI & 0.609 & 0.613 & 0.599 & 0.594 & 0.532 & 0.535 & 0.603 \\
PEM RI & 0.255 & 0.261 & 0.264 & 0.253 & 0.307 & 0.224 & 0.260 \\
PBB & 0.075 & 0.067 & 0.072 & 0.072 & 0.076 & 0.097 & 0.073 \\
IMO/IHO & 0.062 & 0.060 & 0.065 & 0.081 & 0.085 & 0.075 & 0.065 \\
& & & & & & 0.069 & 1.000 \\
\hline
\end{tabular}

Sumber: Olahan Peneliti

VP_F2 sampai

dengan VP_F6 : merupakan vektor prioritas bagi 6 elemen di atas

VP_FCUS : vektor prioritas atas fokus kepentingan tertera pada nomor 2 di atas

VP_FGAB : vektor prioritas gabungan atau Eigen Value (bilangan Eigen) yang merupakan perkalian matriks VP_F2 sampai dengan VP_F6 dengan VP_FCUS
Empat aktor terhadap Model Traffic Separation Scheme (TSS) pada Alur Laut Kepulauan Indonesia (ALKI) I di Selat Sunda Dalam Mewujudkan Ketahanan Wilayah, berdasarkan (1) Elemen Mewujudkan Ketahanan Wilayah. (2) Elemen Mendukung Implementasi Poros Maritim Dunia. (3) Elemen Mendukung Kelancaran dan Keselamatan Lalu Lintas Laut. (4) Elemen Implementasi pasal-pasal UNCLOS 1982, sebagai Konsekuensi Ratifikasi. (5) Elemen Menciptakan Kelancaran Sea Lanes of Communication (SLOC) dan Sea Lanes of Oil Trade (SLOT).

Matriks Eigen Value dari perhitungan vektor prioritas bagi 6 elemen di atas dikalikan dengan vektor prioritas atas fokus kepentingan, hasil tertera pada tabel 3 .

$\begin{array}{ll}\text { NKRI } & \text { : Negara Kesatuan Republik } \\ & \text { Indonesia } \\ \text { PEM RI } & : \text { Pemerintah Republik Indonesia } \\ \text { PBB } & : \text { Perserikatan Bangsa Bangsa } \\ & \text { atau United Nation Organization } \\ & \text { (UNO) } \\ \text { IMO/IHO } & : \text { International Maritim e } \\ & \text { Organization dan International } \\ & \text { Hydrographic Organization }\end{array}$

Hasil tertera pada tabel 3 tersebut di atas, menampilkan indikator-indikator yang tertera pada VP_FGAB, penentuan tingkat kepentingan aktor, berturut-turut tingkat kepentingan NKRI 0.603 , tingkat kepentingan Pemerintah Republik Indonesia 0.260, tingkat kepentingan Penerapan Kebijakan Lembaga Dunia (PBB) 0.073, tingkat kepentingan Masyarakat Maritim Dunia 0.065. Indikator-indikator tersebut menggambarkan tingkat kepentingan NKRI dalam mewujudkan ketahanan wilayah, berdasarkan fokus model TSS padaAlur LautKepulauan Indonesia(ALKI) I di Selat Sunda, adalah yang utama, selanjutnya adalah tingkat kepentingan pemerintah Republik Indonesia, menyusul tingkat kepentingan lembaga dunia (PBB) dan tingkat kepentingan masyarakat maritim dunia yang tergabung dalam $\mathrm{IMO} / \mathrm{IHO}$. 
Gambar 3

Tingkat Kepentingan Aktor Terhadap Model Traffic Separation Scheme (TSS) Pada Alur Laut Kepulauan Indonesia (ALKI) I Di Selat Sunda Dalam Menciptakan Kelancaran SLOC/SLOT

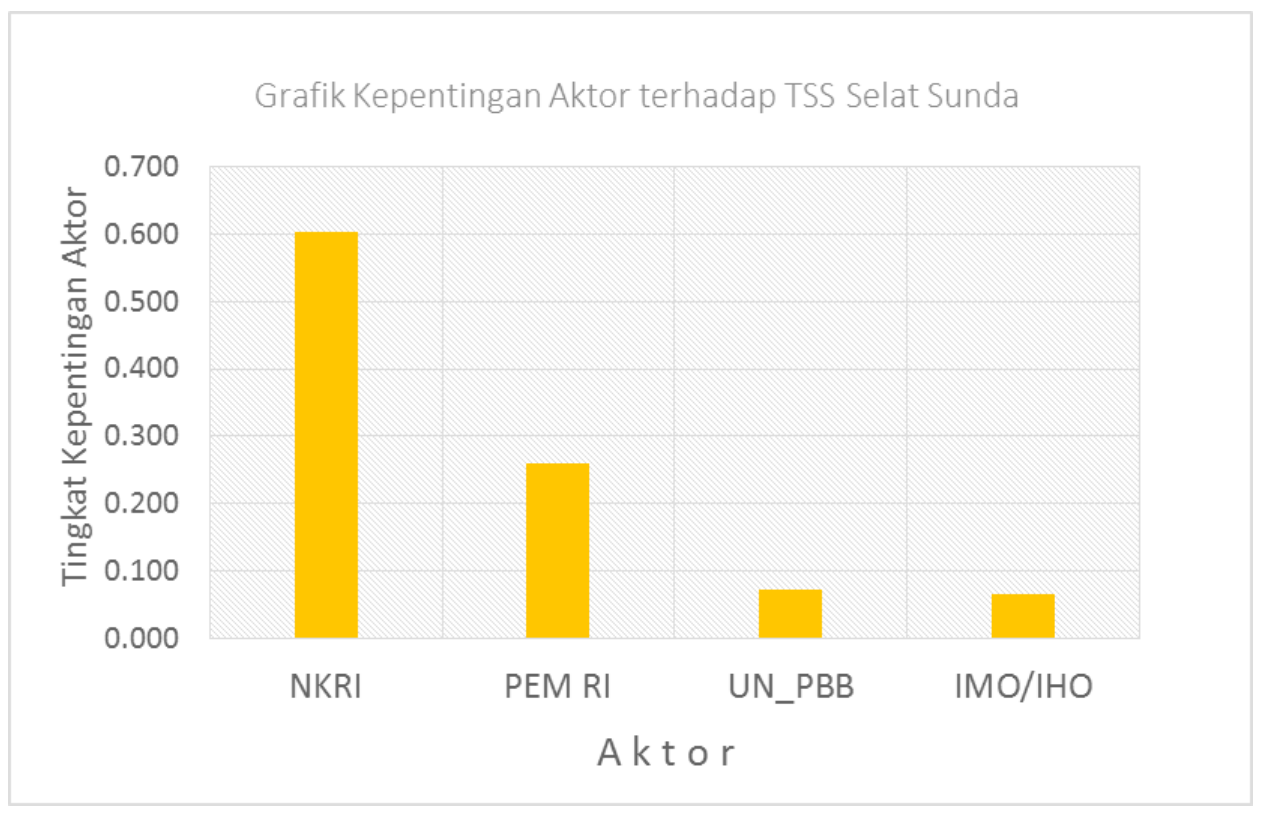

Sumber: Olahan Peneliti

Tabel 4

Hasil Perhitungan Matriks Gabungan Kriteria, Terhadap Model Traffic Separation Scheme (TSS) Pada Alur Laut Kepulauan Indonesia (ALKI) I Di Selat Sunda, Berdasarkan Aktor

\begin{tabular}{lrrrrrr}
\hline & VP_AK1 & VP_AK2 & VP_AK3 & VP_AK4 & VP_FGAB & VP_AKT_GAB \\
\hline TanWil & 0.499 & 0.460 & 0.460 & 0.448 & 0.603 & 0.483 \\
RosMar & 0.117 & 0.128 & 0.130 & 0.129 & 0.260 & 0.122 \\
Lam LaLa & 0.143 & 0.155 & 0.142 & 0.159 & 0.073 & 0.147 \\
AtLin ALKI & 0.105 & 0.090 & 0.105 & 0.090 & 0.065 & 0.100 \\
RapTek_Kom & 0.063 & 0.077 & 0.074 & 0.080 & & $\mathbf{0 . 8 5 2}$ \\
SLOC/SLOT & 0.072 & 0.090 & 0.089 & 0.094 & & \\
\hline
\end{tabular}

Sumber: Olahan Peneliti

Keterangan :

VP_AK1 sd VP_AK4 : merupakan vektor prioritas bagi 4 aktor seperti tertera pada 6.2.2. di atas

VP_FGAB : merupakan vektor prioritas bagi 4 aktor dari Eigen Value tertera pada 6.2.2. di atas

Gambar 3 di atas menampilan grafis hasil perhitungan matriks gabungan pendapat pakar atas elemen-elemen aktor. Grafik menunjukkan bahwa tingkat kepentingan yang paling tinggi
VP_AKT_GAB: vektor prioritas gabungan atau Eigen Value (bilangan Eigen) yang merupakan perkalian matriks VP_AK1 sampai dengan VP_AK4 dengan VP_FGAB

yaitu kepentingan NKRI dengan nilai 0,6. Kepentingan yang paling rendah terhadap TSS di Selat Sunda berdasarkan pendapat pakar atas elemen elemen Aktor yaitu kepentingan 
IMO dan kepentingan IHO serta kepentingan UN PBB.

Enam kriteria terhadap Model Traffic Separation Scheme (TSS) pada Alur Laut Kepulauan Indonesia (ALKI) I di Selat Sunda dalam mewujudkan ketahanan wilayah berdasarkan (1) Ketahanan Wilayah. (2) Implementasi Program Pemerintah RI Poros Maritim Dunia. (3) Kelancaran dan keselamatan lalu lintas laut. (4) Aturan Lintas ALKI sesuai UNCLOS 1982. (5) Penerapan Teknologi Komunikasi. (6) Kelancaran SLOC/SLOT.

Matriks Eigen Value dari perhitungan vektor prioritas bagi 6 elemen dikalikan dengan vektor prioritas atas fokus kepentingan tertera, hasil tertera pada tabel 4 berikut.

Tabel 4 tersebut menampilkan indikatorindikator yang tertera pada VP_AKT_GAB, penentuan tingkat kepentingan Aktor berdasarkan elemen-elemen enam kriteria seperti tersebut di atas, berturut-turut tingkat kepentingan NKRI 0.483, tingkat kepentingan Pemerintah Republik Indonesia 0.122, tingkat kepentingan Penerapan Kebijakan Lembaga Dunia (PBB) 0.147, tingkat kepentingan Masyarakat Maritim Dunia 0.100. Indikatorindikator tersebut menggambarkan tingkat kepentingan NKRI dalam mewujudkan ketahanan wilayah, berdasarkan elemenelemen Kriteria seperti tersebut di atas. Tampilan grafis hasil perhitungan matriks gabungan pendapat pakar tingkat kepentingan aktor berdasarkan elemen-elemen kriteria, tertera pada gambar 4 .

Mengacu pada kepentingan Aktor, elemen-elemen solusi atas fokus Model Traffic Separation Scheme (TSS) pada Alur Laut Kepulauan Indonesia (ALKI) I di Selat Sunda dalam mewujudkan ketahanan wilayah, sebagai berikut (1) Solusi pertama dengan memanfaatkan sistem yang ada saat ini tanpa menambahkan TSS. (2) Solusi kedua dengan membuat TSS menggunakan jalur ALKI yang telah ada. (3) Solusi ketiga dengan membuat TSS menggunakan keseluruhan lebar selat (Selat Sunda).

Gambar 4

Persentase Hasil Perhitungan Matriks Gabungan Kriteria Terhadap Model Traffic Separation Scheme (TSS) Pada Alur Laut Kepulauan Indonesia (ALKI) I Di Selat Sunda Berdasarkan Aktor

Persentase gabungan Kriteria, Model TSS pada Alur Laut Kepulauan Indonesia (ALKI) I di Selat Sunda, Berdasarkan Aktor

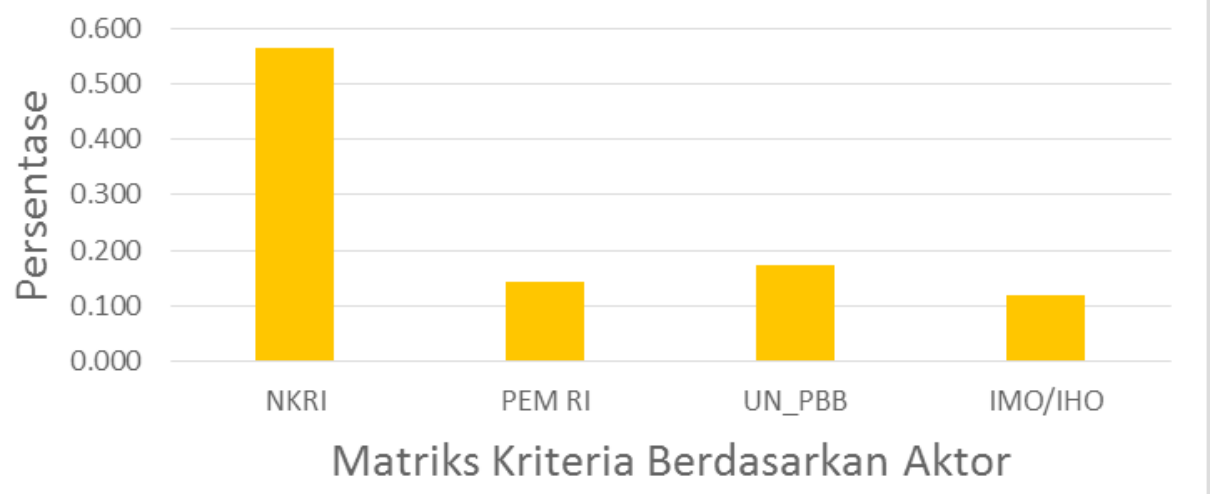

Sumber: Olahan Peneliti 
Tabel 5

Eigen Value Dari Perkalian Matriks Gabungan VP_Solusi 1 SD 4

\begin{tabular}{ccccccc}
\hline SOLUSI & VP_SLSI1 & VP_SLSI2 & VP_SLSI3 & VP_SLSI4 & VP_AKT_GAB & EV \\
\hline EXIST & 0.287 & 0.293 & 0.376 & 0.292 & 0.483 & 0.259 \\
TSS ALKI & 0.610 & 0.597 & 0.498 & 0.600 & 0.122 & 0.501 \\
TSS SELSUND & 0.103 & 0.109 & 0.127 & 0.108 & 0.147 & 0.092 \\
& & & & & 0.100 \\
\hline
\end{tabular}

Sumber: Olahan Peneliti

Keterangan :

EXIST : memanfaatkan sistem yang ada saat ini

TSS ALKI

: TSS menggunakan jalur ALKI yang telah ada.

TSS SELSUND : TSS menggunakan keseluruhan lebar selat (Selat Sunda).

Tabel 5 di atas menampilkan indikatorindikator yang tertera pada $\mathrm{EV}$, penentuan tingkat besaran solusi yang mungkin diterapkan untuk Model Traffic Separation Scheme (TSS), pada Alur Laut Kepulauan Indonesia (ALKI) I di Selat Sunda, dalam mewujudkan ketahanan wilayah, yaitu memanfaatkan sistem yang ada saat ini 0.259 atau 30\%, TSS menggunakan jalur ALKI yang telah ada 0.501 atau 59\%, TSS menggunakan keseluruhan lebar selat (Selat Sunda) 0.092 atau 11\%.

Tampilan grafis Eigen Value Solusi berdasarkan faktor kepentingan, aktor, elemen-elemen kriteria, tertera pada gambar 5 berikut.

Menurut penilaian para pakar (Experts Judgement) berdasarkan empat kepentingan NKRI, Pemerintah RI, Lembaga dunia (PBB) dan masyarakat maritim dunia (IMO/IHO) solusi Model Traffic Separation Scheme (TSS) pada Alur Laut Kepulauan Indonesia (ALKI) I di Selat Sunda dalam mewujudkan ketahanan Wilayah adalah dengan membuat TSS memanfaatkan ALKI yang telah ada.

Gambar 5

Eigen Value Solusi Model Traffic Separation Scheme (TSS) Pada Alur Laut Kepulauan Indonesia (ALKI) I Di Selat Sunda Dalam Mewujudkan Ketahanan Wilayah

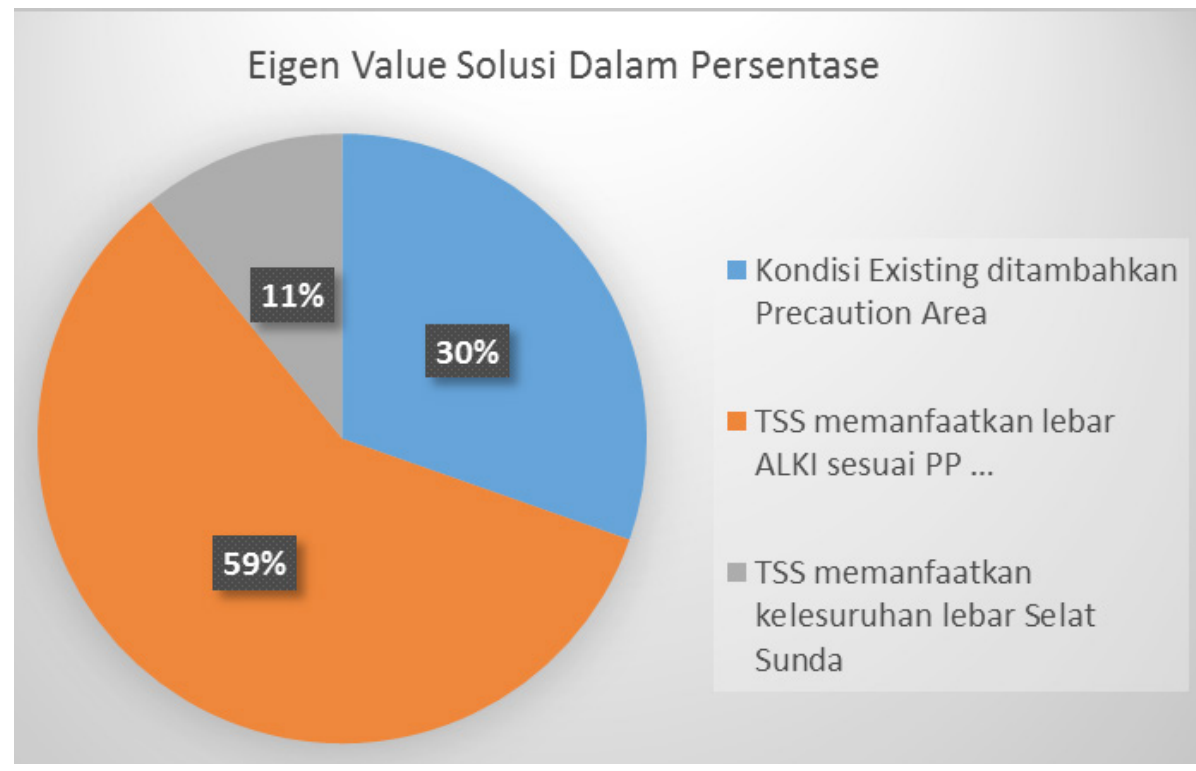

Sumber: Olahan Peneliti 
Dyan Primana Sobaruddin, Armaidy Armawi, Edhi Martono -- Model Traffic Separation Scheme (TSS) Di Alur Laut Kepulauan Indonesia (AlKI) I Di Selat Sunda Dalam Mewujudkan Ketahanan Wilayah

\section{Dampak Penerapan TSS Terhadap Ketahanan Wilayah.}

Lintas Alur Laut Kepulauan dan lintas damai telah diatur dalam UNCLOS 1982, yaitu pada Pasal 53, Hak lintas alur laut kepulauan (right of archipelagic sea lanes passage) khususnya pada pasal 10 yaitu :

"Suatu Negara kepulauan yang menentukan alur laut menurut ketentuan pasal ini dapat juga menetapkan skema pemisah lalu lintas untuk keperluan lintas kapal yang aman melalui terusan sempit dalam alur laut demikian".

Kemudian dipertegas lagi dengan pasal 11 yaitu :

"Kapal yang melakukan lintas alur laut kepulauan harus mematuhi alur laut dan skema pemisah lalu lintas yang berlaku yang ditetapkan sesuai dengan ketentuan pasal ini".

Arief Havas Oegroseno (Deputi Kedaulatan Maritim Kementerian Koordinator Bidang Kemaritiman Republik Indonesia) menyampaikan bahwa pemilihan TSS dari sisi keselamatan navigasi ditetapkan di sebelah barat Pulau Sangiang, yang ada poros ALKI, sehingga akan lebih mudah memantau serta mengindentifikasi kapalkapal yang melintas, apalagi jika dilengkapi dengan VTS. Dengan ditetapkannya TSS di Selat Sunda maka secara tidak langsung nilai strategis Selat Sunda semakin meningkat, oleh sebab itu segala sumber daya mestinya mulai dikerahkan untuk memperkuat dari sisi pengawasan dan pengamanan melalui peningkatan pembangunan surveilance system di selat tersebut (lihat gambar 6).

Gambar 6

Model TSS Pada ALKI I Di Selat Sunda Menurut Para Pakar Lebih Relevan.

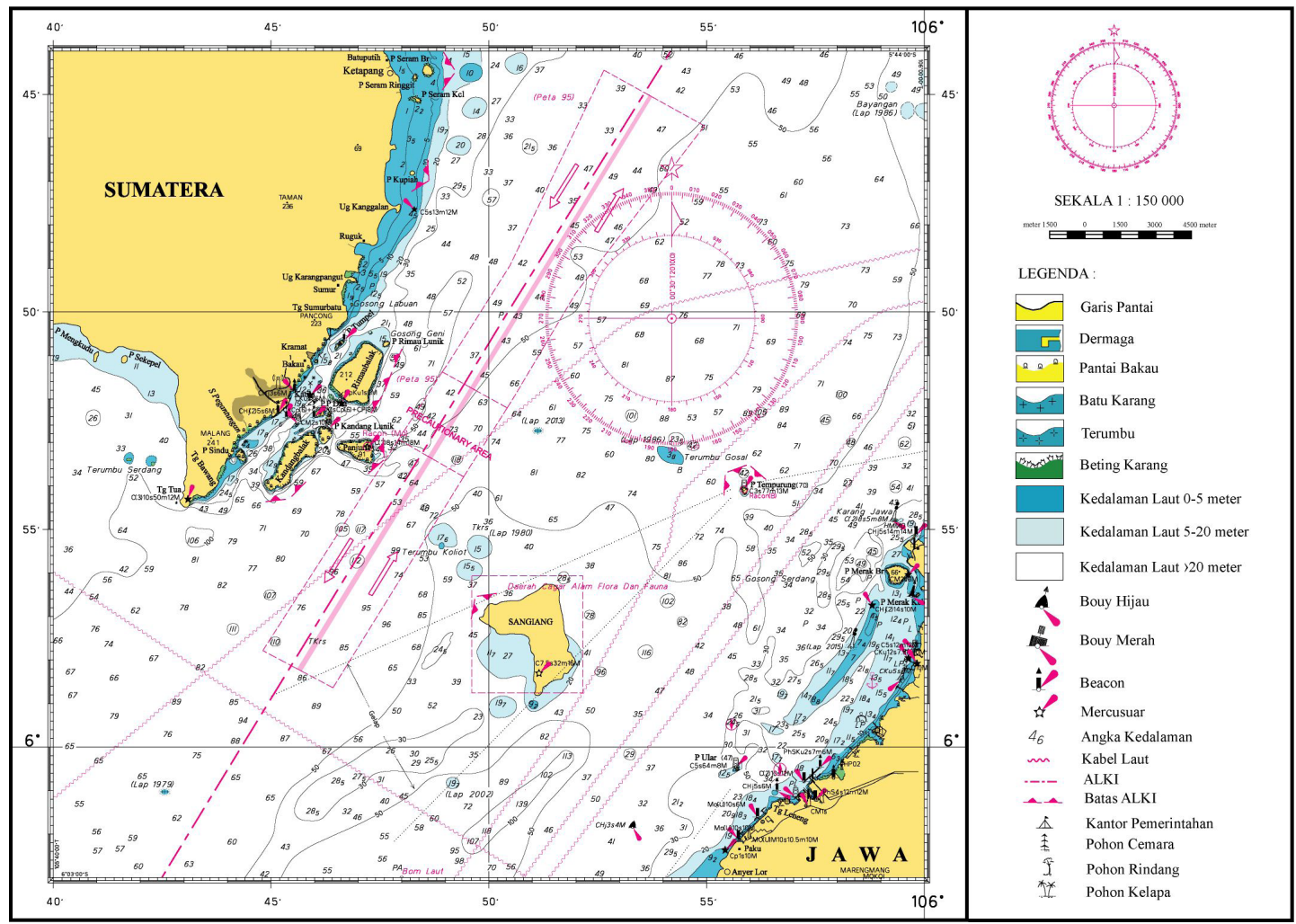

Sumber: Olahan Peneliti 
Setelah pemerintah menetapkan TSS di Selat Sunda yang digambarkannya pada peta laut, sesuai dengan hasil solusi kedua model TSS yang menurut para pakar cocok untuk diterapkan di Selat Sunda, maka kapal-kapal yang melintas di ALKI I saat berlayar di Selat Sunda harus mematuhi aturan TSS yang telah ditetapkan oleh Pemerintah RI. Kapal-kapal tersebut harus berlayar pada koridor TSS yang telah ditetapkan.

Terjaminnya perairan Selat Sunda dari bahaya keamanan, bahaya navigasi pelayaran serta bahaya pencemaran lingkungan melalui pentataan ruang laut di perairan Selat Sunda akan mempengaruhi perkembangan dan pembangunan di wilayah pesisir sekitarnya. Dengan terjaminnya keamanan di laut sebagai akibat dari selalu siap siaganya aparat penegak hukum di laut dalam melaksanakan gelar operasi di perairan Selat Sunda akan memberikan rasa aman pengguna laut. Rasa aman dan nyaman bagi kapal-kapal yang melintas di perairan Selat Sunda diikuti dengan terjaminnya keselamatan bernavigasi tentu menjadi kabar dan berita baik pengguna pelayaran di seluruh dunia. Seiring dengan bertambah padatnya lalulintas di Selat Malaka maka pelayaran dunia akan bergeser melalui ALKI I di Selat Sunda. Uraian tersebut menjadikan peluang bagi pelaku ekonomi di sekitar wilayah sekitar Selat Sunda untuk meningkatkan pembangunan fasiltas pelabuhan, tempat sandar, bongkar muat, logistik dan kebutuhan bahan bakar.

Menurut Dulkadir (2016:109) ekonomi merupakan salah satu aspek kehidupan yang berkaitan dengan pemenuhan kebutuhan bagi masyarakat meliputi produksi,distribusi, serta konsumsi barang dan jasa. Geliat perekonomian di sektor perhubungan laut ini tentu saja akan memberikan efek domino terhadap kesejahteraan masyarakat sekitarnya.
Ketahanan nasional sangat dipengaruhi ketahanan ekonomi, terutama pada saat ini, karena kebutuhan manusia yang semakin banyak dan bermacam-macam (Aji, 2014; 84).

Dengan ditetapkannya TSS di perairan Selat Sunda akan meningkatkan ketahanan wilayah sekitarnya untuk mampu meredam ancaman, ganguan dan hambatan dari segi ekonomi, sosial budaya serta keamanan di sekitar Selat Sunda. Oleh sebab itu diharapkan agar pemerintah segera menetapkan TSS di perairan Selat Sunda dengan memperhatikan aturan-aturan nasional maupun internasional yang mempengaruhi.

\section{SIMPULAN}

Dari uraian di atas maka dapat ditarik simpulan sebagai berikut.

Pertama, berdasarkan hasil perhitungan Matriks Eigen Value dengan mempertimbangkan faktor kepentingan, aktor, elemen-elemen kriteria serta hasil wawancara dan FGD menunjukkan bahwa dalam pemilihan model TSS adalah memanfaatkan lebar ALKI I yang ada di Selat Sunda sehingga model TSS di Selat Sunda yang terbaik adalah solusi-2. Pada solusi-2 TSS berada di sebelah barat Pulau Sangiang, yaitu alur pelayaran di antara Pulau Panjurit dan Pulau Sangiang dengan tetap memperhatikan ALKI I yang sudah ada. Untuk memberikan jaminan keselamatan bernavigasi kapal-kapal yang melitas di TSS tersebut akibat adanya bahaya navigasi di Terumbu Koliot maka diletakkan SBNP. Kapal feri penyeberangan maupun kapal-kapal domistik yang akan berlayar memotong alur pelayaran utama TSS ditetapkan pula daerah kewaspadaan (precaution area) sehingga dapat terhindar bahaya tubrukan di laut.

Kedua, penetapan TSS di perairan Selat Sunda akan meningkatkan ketahanan wilayah 
sekitarnya untuk mampu meredam ancaman, ganguan dan hambatan dari segi ekonomi, sosial budaya serta keamanan di sekitar Selat Sunda. Model TSS Solusi-2 ditinjau dari segi ketahanan wilayah Selat Sunda akan menjamin perairan Selat Sunda dari bahaya gangguan keamanan di laut, bahaya navigasi pelayaran serta bahaya pencemaran lingkungan melalui pentataan ruang laut di perairan tersebut sehingga akan mempengaruhi perkembangan dan pembangunan di wilayah pesisir sekitarnya. Model TSS Solusi-2 akan mempermudah penegak hukum dalam melaksanakan pengawasan karena setiap kapal asing yang akan melewati Selat Sunda harus melewati TSS ini. Rasa aman dan nyaman bagi kapal-kapal yang melintas di perairan Selat Sunda diikuti dengan terjaminnya keselamatan bernavigasi tentu menjadi kabar dan berita baik pengguna pelayaran di seluruh dunia.

Ketiga, penetapan TSS di Selat Sunda agar didahului dengan kegiatan survei hidrooseanografi supaya diketahui data batimetri di sekitar perairan yang akan ditetapkan sebagai TSS, data pasang surut air laut, data kecepatan arus serta data meteorologinya.

Keempat, guna memberikan jaminan keselamatan pelayaran di ALKI I Selat Sunda, pemerintah segera menetapkan TSS di perairan tersebut, memasang SBNP di posisi bahaya pelayaran Terumbu Koliot dan melakukan penataan ruang lautnya. Setelah TSS ditetapkan harus digambarkan di peta laut mauapun ENC untuk dipublikasikan kepada pengguna laut, khususnya bagi kapal-kapal yang berlayar di Selat Sunda serta diumumkan melalui Berita Pelaut Indonesia. Selanjutnya melaporkannya pemberlakuannya di IMO.

Kelima, guna meningkatkan ketahanan wilayah di sekitar perairan Selat Sunda maka pemerintah daerah perlu ikut serta meningkatkan potensi sumber daya kemaritiman seiring dengan ditetapkannya TSS di periaran Selat Sunda.

\section{DAFTAR PUSTAKA}

Aji, Ndaru Sukmono, 2014, "Pembangunan Industri Penambangan Dan Pengolahan Pasir Besi Serta Implikasinya Terhadap Ketahanan Ekonomi Wilayah (Studi Di Kabupaten Kulon Progo Daerah Istimewa Yogyakarta)", Jurnal Ketahanan Nasional, Nomor XXX (2), Program Studi Ketahanan Nasional Sekolah Pascasarjana UGM, Yogyakarta.

Buntoro, K., 2012, Alur Laut Kepulauan Indonesia (ALKI), Prospek dan Kendala. Jakarta: Sekolah Staf dan Komando TNI AL (SESKOAL). , 2016 Konsep "Bagi-Beban"

dalam Keamanan Maritim di Nusantara Indonesia, Jurnal Maritim Pusjianstra Seskoal.

Dishidros, 2008. Kepanduan Bahari Indonesia Wilayah I, edisi tahun 2014.

Dulkadir, Armawy, Armaidy dan HAdmoko, Danang Sri, 2016. Optimalisasi Peran Kodim Dalam Penanggulangan Bencana Banjir Dan Implikasinya Terhadap Ketahanan Wilayah (Studi di Kodim 0614 Kota Cirebon, Jawa Barat)", Jurnal Ketahanan Nasional, vol. 22 no.1, Program Studi Ketahanan Naisonal Sekolah Pascasarjana UGM, Yogyakarta. IHO, 2002. Limits of Oceans and Seas, 4th Edition. Monaco. IHO Publication S-23. IMO, 2016, Ships' routeing. International Maritime Organization. <http://www.imo. org/en/OurWork/Safety/Navigation/Pages/ ShipsRouteing.aspx> (diakses 16 Februari 2016, pukul 20:03). 
IMO, 2016. Convention on the International Regulations for Preventing Collisions at Sea, 1972 (COLREGs). Adoption: 20 October 1972; Entry into force: 15 July 1977. International Maritime Organization. http://www.imo.org/en/ About/Conventions/ListOfConventions/ Pages/COLREG.aspx (diakses 28 Maret 2016, pukul 16:12).

Paonganan, Y, Dr., Zulkipli, R.M. ST dan Agustina, K, S. Kel., 2012, Perspektif Menuju Masa Depan Maritim Indonesia. Jakarta: Yayasan Institut Maritim Indonesia.
Pranoto, 2012. Selat Sunda dalam Konflik Global dari Perspektif Geopolitik. Research Associate Global Future Institute (GFI) Jakarta..

Shahryari, Mansoureh and HM Ibrahim, 'Cross Traffic Movement and Its Risks to Shipping in the Straits of Malacca' (2009) 16(3) 2009 MIMA Bulletin.

\section{Peraturan Perundangan}

Peraturan Menteri Perhubungan Nomor 68 Tahun 2011 Tentang Alur Pelayaran Di Laut. 